\title{
A Survey of Activity-Based Costing Practices in Bahraini Manufacturing Firms
}

\author{
HASAN AL-BASTEKI and SAYEL RAMADAN \\ Assistant Professors \\ Department of Accounting \\ University of Bahrain - Bahrain
}

( Received 28-12-1417(H). and Accepted 12-6-1418(H) )

\begin{abstract}
Studies on Activity-Based Costing (ABC) practices in developing countries are limited. This paper seeks to identify and highlight ABC practices in Bahraini manufacturing firms with respect to extent, motives, difficulties of implementations and reasons as to why some companies have not yet considered ABC.

The study found that a small percentage of Bahraini manufacturing companies are implementing $\mathrm{ABC}$ system. The most important motive for implementing or considering $\mathrm{ABC}$ is that it provides insight into cost causation which helps in cost reduction and control. The provision of more accurate information for pricing decisions and product profitability analysis were also found to be important motives for implementing/ considering ABC. The study also found that the identification of activities, selling $\mathrm{ABC}$ concepts to line employees, and lack of clear understanding of $\mathrm{ABC}$ on the part of production supervisors were the most important difficulties facing ABC adopters. Finally, it is found that satisfaction with existing costing system was the most important reason why many Bahraini companies have not yet considered $\mathrm{ABC}$. The findings of this study are in general consistent with those found by researchers in developed countries.
\end{abstract}

\section{Introduction and Purose}

The relevance of the traditional volume-based cost allocation practices in today's manufacturing environment has been questioned and strongly criticized by accounting academicians, practitioners, and consultants. They argued that traditional cost allocation practices are simplistic and arbitrary, and that allocations do not reflect the pattern of cost causation in firms using advanced manufacturing technologies (Kaplan 1983, 1984, 1986; Johnson and Kaplan, 1987). Thus, the traditional volume-based cost allocation practices distort cost and profit and mislead management (Miller and Vollmann 1985, Cooper 1988, Kaplan and Atkinson 1989, and Swenson 1995). To overcome such deficiencies and to provide more accurate information for management planning and control, Activity-Based Costing (ABC) was proposed. 
Since its origination in the USA in the last decade, ABC is enjoying increasing popularity not only in the USA but also in other developed countries such as Canada, Europe, Australia, and Japan. Survey and case study research showed that many companies in developed countries have considered and implemented ABC system. $\mathrm{ABC}$ also received a great deal of attention in many developing countries over the last few years. This is evident in the number of $\mathrm{ABC}$ workshops and conferences organized in these countries. However, studies on $\mathrm{ABC}$ practices in these countries are limited. This study seeks to bridge such gap and extend the existing literature on ABC practices by examining the extent of $\mathrm{ABC}$ implementation by manufacturing companies in Bahrain. In fact, some researchers in recent years have acknowledged the need for advancing our knowledge of management accounting practices in developing countries (Anthony 1989; Drury and Tayles 1992). This study is a step in this direction.

Specifically, this study has two main objectives: (1) to identify and highlight $\mathrm{ABC}$ practices, benefits, and difficulties in Bahraini manufacturing companies, and (2) to compare the practices found in Bahraini companies with those reported by studies in developed countries. With respect to $\mathrm{ABC}$ practices, the study addresses the following questions:

1. to what extent manufacturing firms operating in Bahrain have implemented or plan to implement ABC system?,

2. what are the factors or reasons that motivated Bahraini manufacturing firms to implement/plan to implement ABC system?,

3. what are the design and implementation difficulties that were encountered by the firms which adopted ABC system?,

4. what are the reasons that led some Bahraini companies to reject $\mathrm{ABC}$ system after considering it?, and

5. what are the reasons for not considering $\mathrm{ABC}$ system by some companies in Bahrain?.

The paper is divided into four sections. Section one provides a review of previous research related to ABC. Section two discusses the research methodology. Section three presents the findings of the study. The last section summarizes and concludes the study.

\section{Previous Research}

Accounting research on $\mathrm{ABC}$ can be classified into three main categories. The first category consists of descriptive and theoretical papers that seek to explain $\mathrm{ABC}$ system, highlight its benefits compared to traditional volume-based costing, and describe how to implement and install such a system (Miller and Vollmenn 1985, Johnson 1988, Shank and Govindarajan 1988, Cooper 1988, 1989, 1990, Kaplan and Atkinson 1989, Miller 1990, 1992, and Glad 1993). The second category is a case study research that describes actual implementation of ABC system in different organizations (Lee 1990, Fisher et al. 1990, Haedicke \& Feil 1990, Jones 1991, Hardy \& Merg 1993, and Norkiewicz 1994). The third is survey research that explores and 
explains $\mathrm{ABC}$ practices in various countries. This category of research is most relevant to this study. Thus, a review of the last category of $\mathrm{ABC}$ research is provided below.

A number of studies reported that $\mathrm{ABC}$ system was widely considered by companies in developed countries. However, the extent to which these companies had actually implemented ABC system is much lower. In the USA, Green and Amenkhienan (1992) found that $45 \%$ of US firms surveyed use, to some extent at least, $\mathrm{ABC}$ system. In the UK, the percentage of firms reported to have considered ABC varies between 32\% (Bright et al., 1992), 37.6\% (Drury et al., 1993), and 48\% (Innes and Mitchell, 1991). However, when it comes to implementation, Innes and Mitchell (1991) reported that $15 \%$ of 187 British management accountants surveyed had decided to install ABC system. Similarly, Drury et al. (1993) reported that $13 \%$ of 303 companies surveyed have implemented or intend to implement ABC system. In Canada, Armitage and Nicholson (1993) found that $29 \%$ of 352 Canadian companies surveyed have considered ABC system, but only 14\% have implemented or were implementing it. Similar results were also reported with respect to companies in Ireland (Clarke 1992), Finland (Lukka and Grenlund, 1994), and Sweden (Ask and Ax, 1992).

A number of reasons was provided by researchers as to why companies may consider $\mathrm{ABC}$ system but end up with a decision not to implement it. Bright et al. (1992) suggested that the most important barriers to the introduction of the ABC system were: (1) cost of change, (2) lack of relevant skills, and (3) the quality of existing supporting data/systems. Davies and Sweeting (1993) analyzed a 366 firms that had informed in the study of Bright et al. (1992) that they at least consider the introduction of $\mathrm{ABC}$. They found that the main reasons for the fact that some of them had not continued the implementation of an ABC system were as follows: (1) the benefits of $\mathrm{ABC}$ appeared to be too little compared with the existing system, (2) lack of resources, and (3) still ongoing analysis dealing with such issues as the new method itself and the training of its users.

The literature on $\mathrm{ABC}$ suggests two main motives or reasons as to why companies consider and adopt $\mathrm{ABC}$ system. First, $\mathrm{ABC}$ improves insight into cost causation which helps in cost control/reduction. As pointed out by Cooper and Kaplan (1991) "the activity based system shows that significant expense reduction can be achieved by reducing set up cost, making production scheduling and material handling more efficient, and reducing the number of parts required to meet final customer product demand." The cost control/reduction motive for ABC was found to be one of the main reasons for $\mathrm{ABC}$ adoption by companies in the USA (Green and Amenkhienan,1992), in Canada (Armitage and Nicholson, 1993), in the UK (Bright et al., 1992), and in Finland (Lukka and Grenlund, 1994).

Second, ABC leads to more accurate cost data. Garrison and Noreen (1994) pointed out that $\mathrm{ABC}$ provides more accurate cost data by increasing the number of cost pools used to accumulate overhead costs and changing the base used to assign overhead costs to products. As a result of having more accurate costs information, managers are in a position to make better decisions relating to pricing, product retention, marketing strategy, and other important decisions. In this regard, research 
on $\mathrm{ABC}$ practices reported that $\mathrm{ABC}$ was considered/adopted by companies because it perceived to provide more accurate cost information for pricing decisions (Armitage and Nicholson, 1993), profitability analysis (Nicholls, 1992), marketing and production decisions (Green and Amenkhienan, 1992), and inventory valuation (Innes and Mitchell, 1994).

Many difficulties/problems associated with the introduction of ABC system were reported by researchers who examined ABC practices. Green and Amenkhienan (1992) found the following to be the major problems associated with the introduction of $\mathrm{ABC}$ system: (1) the increased amount of detailed information needed by the new system, (2) increased paperwork, (3) difficulty in cost driver identification, and (4) insufficient support by top management. Similarly, Cobb et al. (1992) found the following to be the most important problems of implementing ABC: (1) the amount of work involved, (2) the existence of other priorities, (3) lack of staff time, (4) scarce computer resources, and (5) selection of cost drivers. They also suggested that during the implementation phase, the bottleneck is the working time invested in system development. After the first year of $\mathrm{ABC}$ implementation, the most significant problems were linked with the large work-load of system maintenance, and with collection of data concerning cost drivers and activities that cross departmental boundaries. Finally, Armitage and Nicholson (1993) found that difficulties in defining activities, selecting cost drivers, and selling the $\mathrm{ABC}$ concept to line employee are the three problems most often encountered by Canadian firms during the design and implementation of the ABC system.

\section{The Questionnaire}

\section{Research Methodology}

A three-part questionnaire was constructed to collect the data needed for this study. Part one contains four questions covering company's name, age, number of employees, and annual sales. Part two collects information on the significance of manufacturing overhead costs and the methods or approaches used for its allocation. The last part elicits information on the extent of $\mathrm{ABC}$ implementation, the motives for considering it, reasons for rejecting it after a careful assessment, difficulties associated with its introduction, and reasons as to why some companies are not planning to consider it.

Since it is impossible to predict how questionnaire items will be interpreted by respondents, the questionnaire was pilot tested on a small sample of subjects. The results and feedback of the pilot test were used to refine the questionnaire.

\section{The Sample}

A list of manufacturing companies operating in Bahrain was obtained from the Ministry of Industry and Development (State of Bahrain). The list has 332 firms. From this list, companies with 50 workers or more were selected for the study. The reason for limiting the study to companies with 50 workers or more is that smaller firms are less likely to have a cost accounting system and if they do have, they are less likely to be able to afford the cost of studying $\mathrm{ABC}$ systems and implementing the required changes. A total of 49 firms met the above size criterion. 


\section{Procedure}

A group of accounting students were asked to visit each of the 49 firms in the sample and ask the manager of the accounting department to fill in the questionnaire. A total of 37 questionnaires were returned. This represents an overall response rate of 75.6\%. Six of the returned questionnaires were excluded because they were incomplete. Thus, the useable questionnaires were 31 (63\% usable response rate).

\section{Characteristics of the Sample}

Table (1) presents descriptive statistics on the 31 companies examined in this study. Two measures of size were presented in Table 1; number of employees and annual sales. Number of employees for the companies in the sample ranges between 50 and 2700 workers with an average of 368 employee. With respect to annual sales, it ranges between US $\$ 100,000$ and US\$1,802,000,000 with an average of US\$ $100,828,000$. Finally, the average age of the companies in the sample is 17.6 years with 12.3 years standard deviation. Specifically, of the 31 firms only 2 started operations before the year 1960, 4 companies started during the period 1961-1970, 12 companies during the period 1971-1980, 7 companies during the period 1981-1990, and the remaining 6 companies between the years 1991 and 1994.

Table (1)

Descriptive Statistics on the Sample

$$
(\mathrm{N}=31)
$$

\begin{tabular}{|l|c|c|c|c|}
\hline & Age* & $\begin{array}{c}\text { Overhead as \% of Total } \\
\text { Production cost }\end{array}$ & $\begin{array}{c}\text { Number of } \\
\text { Employees }\end{array}$ & $\begin{array}{c}\text { Annual Sales } \\
\text { (US\$ million) }\end{array}$ \\
\hline Mean & 17.613 & $28.9 \%$ & 368 & 100.828 \\
\hline Standard Deviation & 12.368 & $20.9 \%$ & 585 & 353.091 \\
\hline Minimum & 2 & $5 \%$ & 50 & .270 \\
\hline Maximum & 62 & $85 \%$ & 2700 & 1802.000 \\
\hline Range & 60 & $80 \%$ & 2650 & 1801.730 \\
\hline
\end{tabular}

* Age is defined as the difference between the company's year of establishment and the year 1996.

Table (1) also shows that manufacturing overhead as a percentage of total manufacturing costs for the sample firms ranges between $5 \%$ and $85 \%$ with an average of $29 \%$. Thus, on average, manufacturing overhead represents a significant portion of total manufacturing costs for Bahraini manufacturing firms. However, this is not a surprise in today's highly automated manufacturing environment. In fact, the percentage of manufacturing overhead to total manufacturing costs for Bahraini companies is in-line with those found by researchers in other countries. In a survey of companies in Asia, New Zealand, Europe, and North America, Miller et al. (1992) found that the percentage of manufacturing overhead to total manufacturing costs for all companies surveyed was $28 \%$.

\section{Results}

\section{Methods of Allocating Manufacturing Overhead Costs}

Table (2) summarizes the findings with respect to methods of allocating manufacturing overhead costs used by the 31 companies examined in this study. The table shows that the majority of the companies (19 of the 31 firms, or $61 \%$ ) uses single 
cost allocation rate. Units of production is the single most commonly used method. This is followed by direct labor hours method and prime cost method. Of the 12 companies using multiple cost allocation rates for manufacturing overhead, 6 companies use two cost allocation rates, 4 companies use three rates, one company uses four rates, and one company uses five rates. As in the case of companies using single cost allocation rate, the most commonly used methods of cost allocation by companies using multiple cost allocation rates were direct labor hours method and units of production method.

Table (2)

Methods of Allocating Manufacturing Overhead $(\mathrm{N}=31)$

\begin{tabular}{|l|c|c|c|c|c|c|c|}
\cline { 2 - 8 } \multicolumn{1}{c|}{} & Number of Firms & \multicolumn{2}{l|}{} \\
\hline & Total & $\begin{array}{c}\text { Units of } \\
\text { Production }\end{array}$ & $\begin{array}{c}\text { DirectLabor } \\
\text { Hours }\end{array}$ & $\begin{array}{c}\text { DirectLabor } \\
\text { Cost }\end{array}$ & $\begin{array}{c}\text { Machin } \\
\text { Hours }\end{array}$ & $\begin{array}{c}\text { Direct } \\
\text { Material Cost }\end{array}$ & $\begin{array}{c}\text { Prime } \\
\text { Cost }\end{array}$ \\
\hline $\begin{array}{l}\text { Single cost } \\
\text { allocation rate }\end{array}$ & 19 & 6 & 4 & 3 & 3 & 0 & 4 \\
\hline $\begin{array}{l}\text { Multiple cost } \\
\text { allocation rates }\end{array}$ & 12 & & & & & & \\
\hline 1. Two rates & & 3 & 3 & 1 & 4 & 1 & 0 \\
\hline 2. Three rates & & 3 & 3 & 1 & 1 & 3 & 1 \\
\hline 3. Four rates & & 0 & 1 & 1 & 1 & 1 & 0 \\
\hline 4. Five rates & & 1 & 1 & 1 & 1 & 1 & 0 \\
\hline
\end{tabular}

These findings are generally consistent with the findings of survey studies of manufacturing companies in developed countries. Direct labor hours was found to be the most commonly used cost allocation method in the USA (Cohen and Paquette, 1991), the UK, Australia, and Japan (Blayney and Yokoyama, 1991), and Ireland (Clarke, 1992). Blayney and Yokoyama (1991) also found that units of production method is a commonly used cost allocation method in the UK (22\% of the firms surveyed), Australia (20\% of the firms surveyed), and in Japan (16\% of the firms surveyed). However, Cohen and Paquette (1991) reported that only 5\% of the American firms surveyed use units of production method.

\section{Extent of ABC Implementation}

Analysis of the data on the extent of $\mathrm{ABC}$ implementation revealed that relatively small percentage of Bahraini manufacturing companies are currently implementing some form of ABC system [see Table (3)]. Only eight of the 31 companies surveyed (or 26\%) reported that they have an $\mathrm{ABC}$ system in place. However, all these firms are using $\mathrm{ABC}$ system as a supplementary and not a replacement to the traditional volume based costing system. That is, $\mathrm{ABC}$ is used as a stand alone outside the accounting system. This stand alone ABC system might be based on spreadsheet, database, or acquired $\mathrm{ABC}$ package. Six of the eight companies were using $\mathrm{ABC}$ for the last year, while the remaining two companies for more than one year now. 
Table (3)

Extent of Implementing ABC by Bahraini Manufacturing Companies (Frequency Analysis)

\begin{tabular}{|c|l|c|c|}
\hline \multicolumn{1}{|c|}{ Extent of Implementing ABC } & $\begin{array}{c}\text { No. of } \\
\text { Firms }\end{array}$ & \multicolumn{1}{|c|}{$\%$} \\
\hline 1 & $\begin{array}{l}\text { ABC system is currently implemented and it is operating as a replacement for the } \\
\text { traditional volume-based costing system }\end{array}$ & 0 & $0 \%$ \\
\hline 2 & $\begin{array}{l}\text { ABC system is currently implemented and it is operating as a supplementary to } \\
\text { the traditional volume-based costing system (i.e., ABC is used as stand alone } \\
\text { outside the accounting system). }\end{array}$ & 8 & $26 \%$ \\
\hline 3 & $\begin{array}{l}\text { ABC system is currently under consideration but no decision has yet been made } \\
\text { with respect to use/implementation. }\end{array}$ & 5 & $16 \%$ \\
\hline 4 & $\begin{array}{l}\text { ABC system was considered and a decision has been made to } \\
\text { introduce/implement it. }\end{array}$ & 0 & $0 \%$ \\
\hline 5 & $\begin{array}{l}\text { ABC system was considered and a decision has been made Not to } \\
\text { introduce/implement it. }\end{array}$ & 3 & $10 \%$ \\
\hline 6 & $\begin{array}{l}\text { ABC system was not yet considered but we have a plan to consider it in the } \\
\text { coming 12 months. }\end{array}$ & 14 & $45 \%$ \\
\hline 7 & $\begin{array}{l}\text { ABC system was not yet considered and we have no plans to consider it in the } \\
\text { coming 12 months. }\end{array}$ & $\mathbf{3 1}$ & $\mathbf{1 0 0 \%}$ \\
\hline & \multicolumn{1}{|c|}{ Total } & \\
\hline
\end{tabular}

The limited use of $\mathrm{ABC}$ system by Bahraini manufacturing companies is not surprising. $\mathrm{ABC}$ is a new technique that is still not widely adopted even in developed countries like the UK (Innes \& Mitchell, 1991; Drury, 1993), Canada (Armitage and Nicholson, 1993), and Finland (Lukka and Grenlund, 1994).

The majority of the firms in the sample (55\%) indicated that $\mathrm{ABC}$ system was not yet considered in their companies and more than $80 \%$ of these firms suggested that they even have no plans to consider ABC system in the coming 12 months. Table (4) shows the reasons suggested by these companies as to why they didn't consider or plan to consider ABC system. Satisfaction with the existing costing system was suggested as the most important reason as to why Bahraini companies did not consider ABC. Other important reasons include the following: (1) ABC system is not a priority for their management, and (2) nobody in these companies has initiated consideration for introduction of $\mathrm{ABC}$ system.

\section{Motives for $A B C$}

Fourteen of the 31 Bahraini manufacturing firms (or $45 \%$ of the sample) had either implemented or at least considered ABC system. These companies indicated that the most important motive for implementing/considering $\mathrm{ABC}$ is that it provides insight into cost causation which helps in cost reduction and control [ see Table (5) ]. Nine of the 14 companies (or 64\%) suggested that the provision of insight into cost causation which helps in cost control is an extremely important motive for considering ABC. The overall mean of ranks assigned to this motive was 4.14 in a 5 points scale. The second most important motive is that $\mathrm{ABC}$ provides more accurate information for pricing decisions (overall mean 3.93). The provision of more accurate information for product profitability analysis, departments/centers profitability analysis, and inventory valuation and income determination were also suggested as important motives for implementing/considering $\mathrm{ABC}$. The above findings are consistent with previous surveys of US firms (Green and Amenkhienan 1992), UK companies (Nicholls 1992; Bright et al. 1992), Canadian firms (Armitage and Nicholson 1993), and Finnish companies (Lukka and Grenlund 1994). 
Table (4)

Reasons for Not Considering or Planning to Consider ABC System

$(\mathrm{N}=14)$

\begin{tabular}{|l|c|c|c|c|c|c|}
\hline Motive/Reason & $\begin{array}{c}\text { Not } \\
\text { Important }\end{array}$ & & & $\begin{array}{c}\text { Extremely } \\
\text { Important }\end{array}$ & Mean \\
\hline & $\mathbf{( 1 )}$ & $\mathbf{( 2 )}$ & $\mathbf{( 3 )}$ & $\mathbf{( 4 )}$ & $\mathbf{( 5 )}$ & \\
\hline Satisfied with the existing costing system. & $0 \%$ & $0 \%$ & $21 \%$ & $14 \%$ & $65 \%$ & 4.43 \\
\hline ABC system is not a priority for management. & $7 \%$ & $7 \%$ & $14 \%$ & $21 \%$ & $51 \%$ & 4.00 \\
\hline $\begin{array}{l}\text { Nobody in the company has initiated } \\
\text { consideration of an ABC system. }\end{array}$ & $21 \%$ & $7 \%$ & $0 \%$ & $28 \%$ & $44 \%$ & 3.64 \\
\hline $\begin{array}{l}\text { Management lack knowledge of ABC system and } \\
\text { its advantages over traditional costing system. }\end{array}$ & $21 \%$ & $44 \%$ & $21 \%$ & $14 \%$ & $0 \%$ & 2.29 \\
\hline $\begin{array}{l}\text { ABC is not appropriate for the type of } \\
\text { business we are in }\end{array}$ & $28 \%$ & $37 \%$ & $21 \%$ & $7 \%$ & $7 \%$ & 2.29 \\
\hline Most of the costs in our company are fixed & $37 \%$ & $21 \%$ & $28 \%$ & $14 \%$ & $0 \%$ & 2.21 \\
\hline Management resistant to change. & $37 \%$ & $28 \%$ & $28 \%$ & $7 \%$ & $0 \%$ & 2.07 \\
\hline $\begin{array}{l}\text { Management perceive the cost of changing } \\
\text { existing system is too high. }\end{array}$ & $51 \%$ & $21 \%$ & $21 \%$ & $0 \%$ & $7 \%$ & 1.93 \\
\hline $\begin{array}{l}\text { Consultants on ABC are not available in } \\
\text { Bahrain. }\end{array}$ & $58 \%$ & $14 \%$ & $21 \%$ & $7 \%$ & $0 \%$ & 1.79 \\
\hline $\begin{array}{l}\text { Other companies in our industry are not } \\
\text { implementing ABC }\end{array}$ & $72 \%$ & $7 \%$ & $21 \%$ & $0 \%$ & $0 \%$ & 1.50 \\
\hline
\end{tabular}

Table (5)

Motives For Considering ABC System

$(\mathrm{N}=14)$

\begin{tabular}{|l|c|c|c|c|c|c|}
\hline Motive/Reason & $\begin{array}{c}\text { Not } \\
\text { Important }\end{array}$ & & & & $\begin{array}{c}\text { Extremely } \\
\text { Important }\end{array}$ & Mean \\
\hline & $(1)$ & $(2)$ & $(3)$ & $(4)$ & $(5)$ & 4.14 \\
\hline $\begin{array}{l}\text { Improved insight into cost causation which } \\
\text { helps in cost control. }\end{array}$ & $7 \%$ & $7 \%$ & $14 \%$ & $7 \%$ & $65 \%$ & 3.93 \\
\hline $\begin{array}{l}\text { More accurate information for product } \\
\text { pricing. }\end{array}$ & $7 \%$ & $21 \%$ & $0 \%$ & $14 \%$ & $58 \%$ & 3.78 \\
\hline $\begin{array}{l}\text { More accurate information about product } \\
\text { profitability. }\end{array}$ & $21 \%$ & $0 \%$ & $21 \%$ & $21 \%$ & $44 \%$ & 3.50 \\
\hline $\begin{array}{l}\text { More accurate information about } \\
\text { departments/centers profitability. }\end{array}$ & $21 \%$ & $7 \%$ & $14 \%$ & $14 \%$ & $44 \%$ & 3.21 \\
\hline $\begin{array}{l}\text { More accurate data for inventory evaluation \& } \\
\text { income determination. }\end{array}$ & $21 \%$ & $21 \%$ & $7 \%$ & $14 \%$ & $37 \%$ & 3.07 \\
\hline $\begin{array}{l}\text { More accurate information about market } \\
\text { profitability. }\end{array}$ & $21 \%$ & $7 \%$ & $37 \%$ & $14 \%$ & $21 \%$ & 3.00 \\
\hline More accurate performance measures. & $29 \%$ & $14 \%$ & $14 \%$ & $14 \%$ & $29 \%$ & 2.93 \\
\hline $\begin{array}{l}\text { More accurate information about customer } \\
\text { profitability. }\end{array}$ & $29 \%$ & $7 \%$ & $21 \%$ & $29 \%$ & $14 \%$ & 2 \\
\hline
\end{tabular}

\section{Difficulties in the Design and Implementation of ABC System}

Like the implementation of any new system, difficulties are expected in the introduction of $\mathrm{ABC}$ system at both the design stage and the implementation stage. At the design stage, the most important difficulty was the identification of the activities that are performed by the company. Five out of 8 companies that implemented ABC system indicated that identification of activities was an extremely important difficulty that they had to face [ see Table (6) ]. The second important difficulty relating to the design of $\mathrm{ABC}$ system was the identification of cost drivers. These findings are not surprising as other studies also found that the identification of both activities (Armitage and Nicholson, 1993) and cost drivers (Green and Amenkhienan 1992) were major difficulties in the design of $\mathrm{ABC}$ system. 
Table (6)

Difficulties in the Design and Implementation of ABC System

$(\mathrm{N}=8)$

\begin{tabular}{|c|c|c|c|c|c|c|}
\hline Difficulty & $\begin{array}{c}\text { Not } \\
\text { Important }\end{array}$ & & & & $\begin{array}{l}\text { Extremely } \\
\text { Important }\end{array}$ & Mean \\
\hline & (1) & (2) & (3) & (4) & (5) & \\
\hline \multicolumn{7}{|l|}{ Design-Related } \\
\hline $\begin{array}{l}\text { Identifying the major activities performed in } \\
\text { the factory. }\end{array}$ & $0 \%$ & $0 \%$ & $25 \%$ & $12 \%$ & $63 \%$ & 4.38 \\
\hline $\begin{array}{l}\text { Identifying what drove the activities identified } \\
\text { in step } 1 \text { above }\end{array}$ & $0 \%$ & $0 \%$ & $50 \%$ & $12 \%$ & $38 \%$ & 3.87 \\
\hline $\begin{array}{l}\text { Determining the cost of the activities } \\
\text { identified in step } 1 \text { above }\end{array}$ & $25 \%$ & $0 \%$ & $25 \%$ & $50 \%$ & $0 \%$ & 3.00 \\
\hline \multicolumn{7}{|l|}{ Implementation-Related } \\
\hline $\begin{array}{l}\text { Difficulties in selling the } \mathrm{ABC} \text { concept to line } \\
\text { employees . }\end{array}$ & $0 \%$ & $12 \%$ & $25 \%$ & $25 \%$ & $38 \%$ & 3.87 \\
\hline $\begin{array}{l}\text { Lack of clear understanding of } \mathrm{ABC} \text { on the } \\
\text { part of production supervisors. }\end{array}$ & $12 \%$ & $0 \%$ & $38 \%$ & $25 \%$ & $25 \%$ & 3.5 \\
\hline $\begin{array}{l}\text { Lack of appropriate computer software to } \\
\text { support implementation of ABC. }\end{array}$ & $38 \%$ & $0 \%$ & $12 \%$ & $38 \%$ & $12 \%$ & 2.87 \\
\hline $\begin{array}{l}\text { Lack of management appreciation of the } \\
\text { benefits of } \mathrm{ABC} \text { and, thus, their commitment } \\
\text { toward it . }\end{array}$ & $12 \%$ & $38 \%$ & $12 \%$ & $25 \%$ & $13 \%$ & 2.87 \\
\hline $\begin{array}{l}\text { Increased workload of production supervisors } \\
\text { with respect to data collection. }\end{array}$ & $38 \%$ & $12 \%$ & $38 \%$ & $0 \%$ & $12 \%$ & 2.38 \\
\hline $\begin{array}{l}\text { Lack of clear understanding of } \mathrm{ABC} \text { on the } \\
\text { part of company's accountants. }\end{array}$ & $50 \%$ & $12 \%$ & $25 \%$ & $12 \%$ & $0 \%$ & 2.00 \\
\hline $\begin{array}{l}\text { Increased workload of accounting personnel } \\
\text { with respect to data collection, analysis and } \\
\text { reporting. }\end{array}$ & $50 \%$ & $12 \%$ & $38 \%$ & $0 \%$ & $0 \%$ & 1.87 \\
\hline $\begin{array}{l}\text { Accountants' reluctance to change traditional } \\
\text { accounting methods . }\end{array}$ & $63 \%$ & $12 \%$ & $25 \%$ & $0 \%$ & $0 \%$ & 1.63 \\
\hline
\end{tabular}

With respect to difficulties related to implementing $\mathrm{ABC}$ system, companies that implemented $\mathrm{ABC}$ system suggested that selling the $\mathrm{ABC}$ concept to line employees and lack of clear understanding of $\mathrm{ABC}$ on the part of production supervisors were the two most important difficulties that they had to face [ see Table (6) ]. On the other hand, the following were indicated to be of no or little importance as implementationrelated difficulties: (1) lack of clear understanding of ABC on the part of company's accountants, (2) increased workload of accounting personnel with respect to data collection, analysis, and reporting, and (3) accountants' reluctance to change traditional accounting methods.

The finding of this study that the increased workload of accounting personnel with respect to data collection, analysis, and reporting under $\mathrm{ABC}$ system is of no or little importance in the implementation of $\mathrm{ABC}$ system is inconsistent with the findings of other researchers (Green and Amenkhienan 1992; Cobb et al. 1992). A possible explanation for this is that Bahraini companies use a simplified ABC system that focuses on specific aspect(s) of the companies operation and serves as a supplementary to their accounting system. Under such limited implementation of ABC system, the amount of detailed information and work-load of system maintenance is not a major problem. 


\section{Summaray and Conclusions}

This study provided evidence that the adoption of new management accounting practices such as $\mathrm{ABC}$ is not limited to developed nations. In Bahrain, a small percentage of manufacturing firms have started implementing $\mathrm{ABC}$ as a supplementary to their traditional volume-based costing. This is not surprising for a number of reasons. First, in order to survive in today's highly competitive border-less world, firms all over the world are forced to adopt the latest managerial philosophies and practices and $\mathrm{ABC}$ is not an exception. Second, the advancement in information technology made it easy for new accounting methods and techniques to be transferred from developed to developing nations. In Bahrain, this transfer is fueled by two additional factors: (1) the dominance of foreign managers and accountants in Bahraini companies, and (2) the influence of local accountants and managers who were educated in developed nations, especially in the USA and the UK.

The most important motive for implementing or considering $\mathrm{ABC}$ is that it provides insight into cost causation which helps in cost reduction and control. The provision of more accurate information for pricing decisions, product profitability analysis, departments/centers profitability analysis, and inventory valuation and income determination were also suggested as important motives for implementing/considering ABC.

With respect to difficulties in designing and implementing $\mathrm{ABC}$ system, the study found the following to be the most important: (1) the identification of activities, (2) selling $\mathrm{ABC}$ concepts to line employees, and (3) lack of clear understanding of $\mathrm{ABC}$ on the part of production supervisors.

The study also found that satisfaction with the existing costing system is the most important reason as to why some Bahraini companies did not consider ABC. Other important reasons include the following: (1) ABC system is not a priority for their management, and (2) nobody in these companies has initiated consideration for introduction of $\mathrm{ABC}$ system.

A possible extension of this study would be to empirically examine the association between a company's manufacturing characteristics and the use or implementation of ABC system. Cooper (1989) and Garrison and Noreen (1994) provided a list of company-specific characteristics and suggested that companies that have some of the these characteristics or conditions are most likely to benefit from and, thus, introduce $\mathrm{ABC}$ system. Another fruitful extension to this study is to use a field research methodology (such as case study or field study) to examine motives, benefits, and difficulties associated with implementation of $\mathrm{ABC}$ by the eight Bahraini companies that had implemented ABC system. Case studies allow a more direct and detail investigation and provide richer source of information than other research methods (Kaplan, 1986). In fact, the use of multiple research methods to investigate management accounting phenomena was encouraged by accounting researchers since no single research method dominates the others on all criteria (Birnberg, Shields, and Young, 1990). 


\section{References}

Anthony, R.N., (1989) Reminiscences About Management Accounting, Journal of Management Accounting Research, 1, pp. 1-20.

Armitage, H.M., and Nicholson, R., (1993) Activity-Based Costing: A survey of Canadian Practice, Issue Paper, No. 3, Society of Management Accountants of Canada, Issue Paper Series, September.

Ask, U. and Ax, C. (1992) Trends in the Development of Product Costing Practices and Techniques-A Survey of the Swedish Manufacturing Industry. The 15th Annual Congress of the European Accounting Association, Madrid, Spain, 22-24 April.

Birnberg, J. G., M. D. Shields, and S. M. Young (1990) The Case for Multiple Methods in Empirical Management Accounting Research (With an Illustration from Budget Setting). Journal of Management Accounting (Fall).

Blayney, P. and I. Yokoyama (1991) Comparative Analysis of Japanese and Australian Cost Accounting and Management Practices. (Working Paper, The University of Sydney, Sydney, Australia).

Bright, J., R. E. Davies, C. A. Downes, and R. C. Sweeting (1992) The Deployment of Costing Techniques and Practices: A UK Study." Management Accounting Research, pp. 201-211.

Clarke, P.J. (1992) Management Accounting Practices in Irish Manufacturing Firms. The 15th Annual Congress of the European Accounting Association, Madrid. Spain 22-24 April.

Cobb, I., J. Innes, and F. Mitchell (1992) Activity-Based Costing Problems: The British Experience. The University of Dundee, Department of Accountancy \& Business Finance.

Cooper, R. (1988) The Rise of Activity-Based Costing - Part I. Journal of Cost Management for the Manufacturing Industry (Summer).

(1989) The Rise of Activity-Based Costing: Part Three. Journal of Cost Management for the Manufacturing Industry, (Fall).

(1990) Implementing an Activity-Based Costing System. Journal of Cost Management for the Manufacturing Industry, (Spring), pp. 33-42.

Cooper, R., and Kaplan, R.S., (1991) The Design of Cost Management Systems, New Jersey: Prentice-Hall.

Cohen, J. and L. Paquette (1991) Management Accounting Practices: Perceptions of Controllers, Journal of Cost Management (Fall).

Davies, R.E., and Sweeting, R.C., (1993) Accounting Innovations and Development of Manufacturing Cost Management Systems, The 16th Annual Congress of the European Accounting Association, Finland.

Drury,C. and M. Tayles (1992) Some Empirical Findings on the Current State of Management Accounting in the UK. EIASM Workshop on Cost Accounting in Europe: Past Traditions and Current Trends, Brussels, December .

Drury, C., S. Braund, P. Osborne, and M. Tayles (1993) A Survey of Management Accounting Practices in UK Manufacturing Companies, London: ACCA.

Drury, C., and Tayles, M., (1994) Product Costing in UK Manufacturing Organizations, European Accounting Review, pp. 443-469.

Fisher, R, G. Frank. and A. Wilkie (1990) Implementing Activity-Based Costing: Lessons from the Gen Corp Experience. Corporate Controller (September/October), pp. 5-20.

Garrison, R. H. and E. W. Noreen (1994) Managerial Accounting-Concepts for Planning, Control, Decision Making,, Irwin, New York.

Glad, E. (1993) Implementation Considerations for an ABC System. Management Accounting (UK) (July/August), pp. 29-32. 
Green, F.B. and F.E. Amenkhienan (1992) Accounting Innovations: A Cross-Sectional Survey of Manufacturing Firms. Journal of Cost Management for the Manufacturing Industry, (Spring), pp. 58-64.

Haedicke, J. and D. Feil (1991) In a Dad Emnionment Hughes Aircraft Sets the Standard for ABC Management Accounting (US) February, pp. 29-33.

Hardy, A. and M. Merg (1993) ABC Puts Accountants on Design Team at HP. Management Accounting (US), September.

Innes, J. and F. Mitchell (1991) ABC: A Survey of CIMA Members. Management Accounting (UK), October, pp. 28-30.

Innes, J., and Mitchell, F., (1994) A Survey of Activity Based Costing in the UK, University of Edinburgh Working Papers.

Johnson, H. T. and Kaplan, R. S. (1987) Relevance Lost: The Rise and Fall of Management Accounting, Boston, Mass, Harvard Business School Press.

Johnson, H. T. (1988) Activity-Based Information: A Blueprint for World- Class Management Accounting, Management Accounting (US), June, pp. 23-30.

Jones, L.F. (1991) Product Costing at Catarpillar. Management Accounting (US) February, pp. 34-42.

Kaplan, R. S. (1983) Measuring Manufacturing Performance: A New Challenge for Managerial Accounting Research, The Accounting Review, October.

(1984) Yesterday's Accounting Undermines Production, Harvard Business Review, July/August.

(1986) The Role for Empirical Research in Management Accounting, Accounting, Organizations, and Society, pp. 429-452.

and Atkinson, A.A. (1989) Advanced Management Accounting, Englewood Cliffs, N.J., Prentice Hall.

Lee, John Y. (1990) Activity-Based Costing at Cal Electronic Circuits, Management Accounting (US), October, pp. 36-38.

Lukka, K. and M. Grenlund (1994) Cost Accounting Practice in Finland, Paper Presented at the 17th Annual Congress of the European Accounting Association, Venice, Italy, April 16-18.

Miller, J.G. and T. E. Vollmann (1985) The Hidden Factory. Harvard Business Review, September / October.

Miller, J. (1990) The Best Way to Implement an Activity-Based Cost Management System. Corporate Controller (September/October), pp. 8-13, 32. (1992) Designing and Implementing a New Nost Management System. Journal of Cost Management, Winter, pp. 41-53.

A. DeMeyer, and J. Nakane (1992) Benchmarking Global Manufacturing, Homewood, IL., Irwin.

Nicholls, B. (1992) ABC in the UK - A Status Report.” Management Accounting (UK), May, pp. $22-23$.

Norkiewicz, A. (1994) Nine Steps to Implementing ABC. Management Accounting (US), April, pp. 28-33.

Shank, J. K. and V. Govindarajan, (1988) The Perils of Cost Allocation Based on Production Volumes, Accounting Horizons, December, pp. 71-79.

Swenson, D., (1995) The Benefits of Activity-Based Cost Management to the Manufacturing Industry, Journal of Management Accounting Research, Fall, pp. 167-180. 


$$
\text { تطبيق أسلوب التكاليف على أساس النشاطر كات الصناعية البحرينية: دراسة ميدانية }
$$

$$
\text { أستاذان مساعدان البستكي و صايل رمضان - قسم المحاسبة }
$$

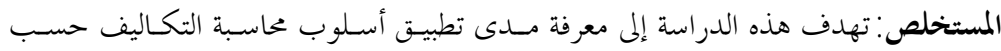

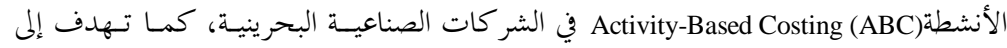

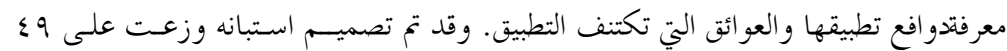

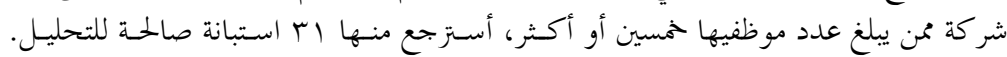

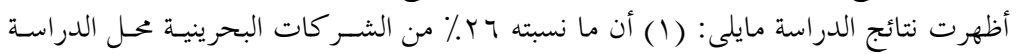

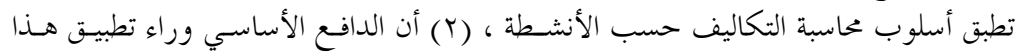

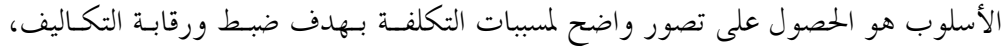

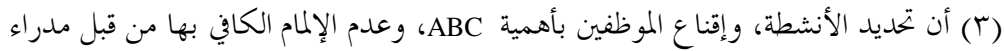

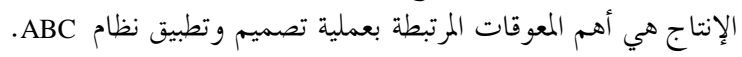

